\title{
CLINICAL SURVEY MANAGEMENT - CHALLENGE OF THE DAY
}

\section{Kozureva Olena ${ }^{1}$ \\ Sumets Oleksandr ${ }^{2}$}

\section{DOI: https://doi.org/10.30525/978-9934-571-89-3_130}

Clinical survey is an important stage in the development of modern medicines for both Ukrainian pharmaceutical manufacturers and for global pharmaceutical companies. Due to this survey, pharmaceutical products, the efficacy of which is proved and investigated safety profiles are available to the pharmaceutical market, while the patients have access to innovative treatments. On the other hand, the development of clinical survey contributes to the creation of new jobs, as well as the introduction of a medicines in the production and health care system.

Ukraine has high potential for its inclusion into international clinical survey projects, which in their turn, in a difficult economic situation, will provide free access to innovative drugs and advanced medical technologies for patients. Furthermore, foreign investments in the health sector by pharmaceutical companies can improve the overall trade balance of the country (services export), increase the volume of financing to the economy and the health care system of Ukraine.

Clinical survey, as a kind of experimental research, put forward stringent requirements for ethical aspects, management, planning, organization, monitoring, reporting and other components. The quality assurance of these components is impossible without highly trained personnel who have undergone appropriate training.

Maintaining and proving the proper level of professionalism is becoming more and more relevant to employees as test sites, as well as pharmaceutical companies and contract research organizations. The process of studying during various trainings, the quality of which differs widely and does not always meet the current educational requirements and their value, cannot be adequately equal to the special education of the respective direction. In our opinion, the most profound knowledge, including the ethical aspects of clinical survey, its administration, planning, organization, observation (supervision, monitoring), reporting, etc., can only be obtained within the course of studying at a higher educational establishment, where it is possible to qualitatively, fully and comprehensively prepare a specialist. Only a profile university can provide an appropriate level of teaching and methodological documentation and knowledge control. A full-fledged educational program should provide an opportunity for professional development and improvement of a specialist of any level.

Taking into account the realities of time and international requirements in the field of clinical research, on the initiative of the Department of Clinical Pharmacology and Clinical Pharmacy, the Department of Management and Administration, supported by

\footnotetext{
${ }^{1}$ National University of Pharmacy, Ukraine

${ }^{2}$ National University of Pharmacy, Ukraine
} 
the National Pharmaceutical University's rectorate, opening a new educational and professional program "Management of Clinical Research" was proposed for the second (master's) level in the field of knowledge 07 Management and administration, specialty 073 Management.

In order to determine the need for training specialists in the field of clinical survey management in Ukraine, an analysis of informational references regarding the examination of materials of drugs clinical trials by the Department of Expertise of Preclinical and Clinical Trials Materials of the State Expert Center of the Ministry of Health of Ukraine for the last five years was conducted [1], the number of test sites (TS) in Ukraine involved in the implementation of clinical trials was estimated [2]. According to the results of the survey, we can say that today, approximately 7 large contract research organizations (CROs) are active on the market of clinical research of Ukraine. They applied for 40-55\% multicenter clinical trials in our country, as well as 38 smaller CROs (45-50\% of studies). Each of these CROs includes at least 5 people who are directly involved in the planning, organization, conduct and monitoring clinical trials.

Domestic applicants for pre-registration clinical trials usually do not involve TS for clinical trials, but have their own structural units that deal with this issue. According to our estimation, 5 large producers (which provide up to $55-70 \%$ of preregistration trials), as well as 14 smaller ones, work steadily in the domestic market of clinical research. The structural divisions dealing with clinical trials in each of these enterprises comprise an average of 5-10 people. Thus, we can conclude that in Ukraine at least 500 people work in the field of clinical research as part of the structural subdivisions of domestic pharmaceutical production.

Estimation of the number of domestic TS involved in the implementation of clinical trials has demonstrated that their number in the last 5 years varies within 500-700 units. Each of these TS performs from 1 to 10 clinical trials, thus we can assume that at least 1,000-1500 doctors are performing research as responsible investigators, survey coordinators and doctors, co-researchers, quality specialists, etc. Taking into account all of the above, the estimation of the labor potential of domestic specialists involved in various functions in the field of management of clinical trials is approximately 1500-2000 people having different basic education and experience in the trials.

In addition, in order to substantiate and assess the need to open a new educational and professional program "Clinical Survey Management" in Ukraine for the second (master) level in the field of knowledge 07 Administration and Administration, specialty 073 Management, the Department of Clinical Pharmacology and Clinical Pharmacy at the National Pharmaceutical University held 2016-2017 the questionnaires with the specialists of the research sites (TS), CROs, pharmaceutical manufacturers - survey sponsors and staff of the State Expert Center Ministry of Health of Ukraine, involved in planning, conducting and evaluating CR and their regulatory control. The total number of respondents was 193 specialists in the sphere of CR $(61 \%$ - women, $39 \%$ - men) at the age of 22-55 years old. 
The distribution by education demonstrated that 166 people (86\%) have medical education, $9(4.7 \%)$ - pharmaceutical, 7 people $(3.6 \%)$ - biological or other education, and 4 respondents $(2.1 \%)$ have two educations, one of which is medical.

It should be noted that 87 respondents $(45 \%)$ participated in more than two CRs (39 of them (20\%) conducted 3-5 CR), 61 respondents (32\%) 1-2 CR, while 45 respondents $(23 \%)$ did not take part in conducting CRs, but plan to do this in the near future.

The distribution by the workplace demonstrated that among the respondents there were 73 representatives $(37.8 \%)$ of medical and preventive care establishments (MCE/PCE), 62 members (32.2\%) of medical/pharmaceutical high educational establishments, 10 employees (5.2\%) of pharmaceutical companies, contract research organizations (CROs) - 10 people (5.2\%), 23 representatives $(11.9 \%)$ of regulatory bodies and others -7 persons (3.6\%). It should be noted that respondents $(4.1 \%)$ noted two places of work, one of which is MCE/PCE, and another is CRO, pharmaceutical company or regulatory body.

The analysis of respondents' opinions regarding the ways to ensure the quality of work of those involved in clinical trials and bioequivalence showed that, in general, $68.6 \%$ of respondents considered appropriate to obtain special managerial education in this area; $15.7 \%$ consider the regulatory and regulatory support for these studies to be sufficient, as well as the establishment of a system of standard operating procedures at all levels involved in such survey; $7.8 \%$ respondents consider that periodic trainings in the performance of the functions of planning, organization, monitoring and compliance with the ethical requirements of clinical research, as well as on the issues of Proper clinical practice and modern regulatory requirements for conducting clinical trials is sufficient; $17.8 \%$ of respondents consider it necessary to implement all of the above-mentioned components.

An assessment of the importance of proper education for conducting clinical trials and bioequivalence was conducted on the following scale: "yes" - new educational services for clinical research are needed; "No" - not necessary; "I do not know" - I do not have a clear idea on this issue. A qualitative analysis of this assessment, based on the results of a general survey of specialists, demonstrated that the expert opinions regarding the correspondence of existing educational services to the requirements and realities of today were divided as follows: $64 \%$ - research site managers, $33 \%-$ survey doctors, $42 \%$ - regulators and 57\% - monitors (employees of pharmaceutical companies, industries, contract research organizations) consider it necessary to open a new specialty in clinical research.

The combination of the results of both studies allows us to conclude that there is a significant need for training specialists in the field of clinical trials in Ukraine under the new educational-professional program "Management of clinical trials" (educational qualification level "Master", specialty "Management", Public Health Manager (Public Health Manager)", while the target audience of potential applicants for this program today is approximately 500 people. The opening of such an educational and professional program will facilitate the expansion of the health care institutions', pharmaceutical manufacturers' and scientists' capacity to engage in 
international survey projects and deepen the integration of our country into the world of scientific and industrial space.

\section{References:}

1. Informatsiya shchodo mists provedennya klinichnykh vyprobuvan. URL: http://www.dec.gov.ua/ index.php/ua/ekspertiza-materialiv-doklinichnikh-ta-klinichnikh-viprobuvan/informatsiya-shchodomists-provedennya-klinichnikh-viprobuvan

2. Informatsiyna dovidka shchodo provedennya ekspertyzy materialiv klinichnykh vyprobuvan likarskykh zasobiv. URL: http://www.dec.gov.ua/index.php/ua/ekspertiza-materialiv-doklinichnikhta-klinichnikh-viprobuvan/aktualna-informatsiya 